\title{
LEARNING AND RELATIONSHIP ORIENTATION. AN EMPIRICAL EXAMINATION IN EUROPEAN MUSEUMS
}

\begin{abstract}
The purpose of this paper is to assess the interrelations between learning orientation, innovation strategy, relationship orientation and economic and social performance in the management of cultural organizations such as museums. We first provide a review of the literature addressing the main constructs involved in the research: learning orientation, innovation, relationship orientation and performance and we detail the model's hypotheses reflecting the interrelations amongst the proposed variables. Building on extensive literature, a model is developed and empirically tested using survey data collected from 491 European museums in Spain, France, Italy and the United Kingdom. Data are analyzed through structural equation modelling. In the present study, evidence is found to support the positive and significant link between learning orientation and internal (organizational innovation) as well as external (relationship orientation) changes in museums. Further, we find that organizational innovation and relationship orientation aid the introduction of greater technological developments in these organizations. We also find evidence to support the idea that learning orientation, innovation strategy and relationship orientation impact the economic and social performance of museums. Findings clearly show that achieving organizational objectives through learning processes necessarily entails the introduction of internal changes -innovation-, and external relationships -relationship orientation.
\end{abstract}

Key words. Learning orientation; relationship orientation, innovation; museum; social and economic performance. 


\section{Introduction}

The goal of the present research is to provide an in-depth understanding of the critical issues involved in learning orientation in museums, and specifically to assess the interrelations between learning orientation, innovation strategy, relationship orientation and economic and social performance in the management of cultural organizations such as museums. Museums are perceived as organizations in which both for-profit and nonprofit concerns merge. Museums may be perceived as non-profit organizations, in which social objectives prevail (education, conservation, custody, etc.). However, they may also be easily likened to for-profit organizations, since they pursue commercial goals and financial objectives (increased visitor numbers and their own revenue). Indeed few pursue purely non-profit ends, precisely because in the current climate they need to generate income in order to survive. This twin nature of museums thus increases interest in exploring the impact of learning orientation on innovation strategy, relationship orientation, and performance. Moreover, few works have to date analysed the role of organizational learning in museums (Garrido and Camarero, 2009).

Organizational learning is an ongoing process through which an organization interprets and assimilates information with a view to engendering knowledge which can be reflected in behavioural models helping to achieve the organization's goals. Chang (2007) describes organizational learning as a process that involves the collection of external data (for example, customers) and the internal development of new processes and product ideas (such as $\mathrm{R} \& \mathrm{D}$ ). It seems reasonable to assume that achieving museums' goals through learning processes involves the introduction of internal changes -organizational and technological innovation- as well as changes in external relations -relationship orientation. However, empirical research into organizational 
learning, innovation, relationship orientation and their impact on performance in nonprofit organizations has thus far been fragmented, incomplete and at times non-existent. To the best of our knowledge, previous research into the non-profit sector has focused on the following issues: a) exploring the link between learning orientation and innovation (Yim-Teo, 2002; Berta et al. 2005; McDonald, 2007); b) analyzing the differences in the process of innovation between for-profit and non-profit organizations (Barczak et al. 2006; Hull and Lio, 2006); c) examining the relation between innovation and performance (Burt and Taylor, 2003; Voss et al. 2006); and d) assessing the impact of organizational learning on performance (Grieves and Mathews, 1997; Zeilstra, 2003; Barrett et al. 2005).

In this context, the contribution of the paper is twofold. First, we distinguish three facets of learning orientation -commitment to learn, open-mindedness and a shared vision- and provide evidence of the direct effect of learning orientation on the museum's economic and social performance. Secondly, we demonstrate that museums' learning orientation is an incentive for museums to innovate and to develop long-term external relationships. In this way, the impact of learning orientation on performance is also indirect through changes in the organizational structure, staff's new capabilities, closer relationships with friends and donors, and the use of technologies that improve both management and visitor experience.

The paper is structured as follows. We first provide a review of the literature addressing the main constructs involved in the research: learning orientation, innovation, relationship orientation, and performance, and we detail the model's hypotheses, reflecting the interrelations amongst the proposed variables. We then seek to test the hypotheses by contrasting a sample of European museums in Spain, France, Italy, and 
the United Kingdom. The findings, conclusions and main implications are presented in the final sections of the work.

\section{Theoretical background: organizational learning}

Senge (1990) defined learning organizations as those that are continually adapting to their changing (complex, dynamic, and unpredictable) environment. When environmental uncertainty is high, both for-profit and non-profit organizations need sustainable competitive advantages in order to survive, forcing them to implement strategies which enable them to procure superior value for consumers (Hult et al. 2003). Numerous authors (e.g. Sinkula, 1994; Hult et al., 2000, Slater and Narver, 1995) perceive organizational learning as a dynamic capability that enhances an organization's ability to achieve and maintain competitive advantage in dynamic environments thanks to the various skills and abilities which such organizations can drawn on for learning and absorbing knowledge (Easterby-Smith and Araujo, 1999).

Organizational learning involves an organization's enhanced capacity to respond by developing a greater understanding and awareness of its environment, leading to improved organizational efficiency (Argyris and Schön, 1978; Fiol and Lyles, 1985). This capacity to learn promotes a continuous improvement in organization structure. The idea of organizational learning is clearly linked to the concept of learning orientation defined as a series of organizational values affecting an organization's willingness to create and use knowledge. Sinkula et al. (1997) propose three dimensions of learning orientation: commitment to learn, open-mindedness and shared vision.

- Commitment to learn concerns the organization's involvement to acquire knowledge and to promote learning through its employees. A learning culture is supported by managers and can be extended to employees through training programs. An organization committed to learning can enhance its innovation capability in three 
ways (Calantone, et al., 2002). First, it is more likely to be committed to innovation, have state-of-the-art technology, and use that technology in innovations. Second, the organization has the knowledge and ability to understand and anticipate customer needs so as to meet them before competitors do. Third, an organization committed to learning is likely to have a greater innovation capability than competitors.

- Open-mindedness involves the willingness to critically evaluate routines and to embrace new ideas. Questioning preconceived ideas or assumptions enables fresh ideas and viewpoints to be taken up. This will to unlearn current ways of thinking allows firms to cope with rapidly changing technology and turbulent markets, all of which requires an ability to manage change (Calantone et al., 2002).

- Finally, a shared vision is a common notion of what the organization should be in the medium and long term. The board is involved in the design of the organization's future and shares its perception of the organization's future with all the junior levels. From a marketing perspective, learning orientation leads to greater heterogeneity in the nature and scope of organizational knowledge, thereby generating improved marketing efficiency and providing end-users with greater value (Sinkula et al., 1997; Day, 1994). In fact, the study of learning orientation has become firmly established amongst marketing scholars. Learning orientation has been related to consumer orientation (Hult and Ferrel, 1997; Hult, Ketchen and Reus, 2001), launch of new products (Baker and Sinkula, 1999b), marketing relationship or market orientation (Santos, Sanzo, Álvarez, Vázquez, 2005), and innovation (Calantone, et al., 2002).

In the case of non-profit organizations, applying the notion of organizational learning is a relatively new idea. Hull and Lio (2006) contend that this delay may be due to the low tolerance to risk inherent in this kind of organization, which negatively impacts their capacity to learn and stifles any favourable environment in which to innovate. The lack 
of (formal and informal) communication and coordination in these organizations hinders organizational learning (Beer and Eisenstat, 2000). In spite of these barriers, organizational learning might lead to a change in values (Argyris and Schön, 1978), skills (Fiol and Lyles, 1985), systems and structures (Levitt and March, 1988), as well as innovation and competitiveness (Nason, 1994).

For the case of museums, we posit that changes within the organization focused on learning occur at both the internal as well as external level. Internal level refers to the changes required in organizational structure and in management style which are key to the organization's new philosophy and the technologies and resources applied to the service offered. At an external level, changes focus on the policies which place the emphasis on the relations with the target public: essentially the visitors and donors.

\section{Organizational learning and the implementation of internal and external changes}

\subsection{Organizational learning and internal changes in museums}

Many authors concur as to the positive link between organizational learning and innovation in the for-profit sector, (Hurley and Hult, 1998; Weerd-Nederhof et al. 2002, Ismail, 2005; Salim and Sulaiman, 2011; Calisir, Cigdem and Guzelsoy, 2013). For non-profits, however, few works have addressed the organizational learning-innovation link: Yim-Teo (2002), in the area of public administration, Berta et al. (2005), for the health service sector, or Cullon and Cullon (2011) are some examples. In the case of cultural organizations, organizational learning stimulates creativity, making it a strategic resource capable of promoting innovation and generating competitive advantage as well as local or regional development (Florida, 2005; European Commission, 2006). By adopting a commitment to learning throughout the organization, non-profits can ensure innovation and performance (Murray and Carter, 2005). 
In museums the most common innovations are improvements and changes in certain aspects of the services provided, advances in the technology used (digital catalogues, virtual visits, or web publications) as well as the application of new management styles which adopt a business rather than a custodial approach. In short, innovations which are central to current museum management fall into two groups: (1) Technological innovations related to technology applied to products, services or production processes for such products or services; and (2) Organizational innovations linked to organizational structure or administrative processes. It entails innovations in the organizational structure of museums to embrace departments devoted to administration, marketing or communication, and by including managers from a business background. Indeed, there are already museums whose organizational structure reflects this twopronged managerial apparatus (manager and curator).

In the case of museums, learning orientation should primarily affect the implementation of new business-oriented management and organizational systems for museums. Organizational change will subsequently impact their overall capacity to develop better services, thus influencing the use of new technologies in the management and presentation of exhibits. Therefore, museums whose staff come from a range of backgrounds (art, history, business management, etc.) and have adopted a business approach, will be more involved in the task of improving offer and services through technological innovations (Camarero and Garrido, 2008). Then:

H1. Learning orientation in museums positively impacts organizational innovation.

$\mathrm{H} 2$. Organizational innovation has a positive influence on technological innovation.

\subsection{Learning orientation and external relationships in non-profit organizations}

In the context of consumer relationships, relationship orientation could be defined as an organization engaged in proactively creating, developing and maintaining committed, 
interactive and profitable exchanges with selected customers over time (Camarero, 2007). Palmatier et al. (2008) indicate that relationship orientation might capture either the organizations's or individual's underlying inclination to seek out or avoid relationship exchanges across each exchange opportunity, and define a party's relationship orientation as its desire to engage in a strong relationship with a current or potential partner to conduct a specific exchange.

Relationship orientation is particularly relevant in museums, since there are many stakeholders (visitors, members, donors, travel agencies, employees, volunteers, public administration, sponsors, residents, etc.) who can prove influential to the museum's objectives and strategies.

As regards the impact of organizational learning on relationship orientation, it would seem logical to assume that one goal of learning is to maintain long-term relations, at least with the organization's strategic clients (Santos, et al., 2005). In this vein, Webster (1992) indicates that the desire to learn involves establishing relations with clients, suppliers, and other market agents. In fact, learning has been linked to a number of outcomes relating to relationships with customers: market orientation (Baker and Sinkula, 1999a), relationship commitment (Johnson and Sohi, 2003), long-term relationships (Santos et al., 2005), and customer satisfaction (Slater and Narver, 1995). Building on Slater and Narver's (1995) argument that customer satisfaction is affected by organizational learning, we establish relationship orientation to be a result of learning orientation - a knowledge-based view. A number of theoretical studies have argued that organizations provide superior value to customers, reflecting a more substantive customer orientation, when their organizational culture fosters learning behaviour that leads to improvements in effectiveness or efficiency (e.g. Saxe and Weitz, 1982; Slater and Narver, 1995; Williams, 1992). 
Based on this empirical evidence, we posit that learning orientation for museums will be reflected in the pursuit of closer relations with the target public, mainly visitors and donors. A commitment on the part of the whole organization towards learning and encouraging fresh ideas and solutions is linked to new ways of conceiving cultural activities, the traditional mission of conserving and preserving giving way to another key mission for museums: active participation of the target public. A relationship with donors and visitors which is perceived as close and long-term is seen as a hallmark of a cultural organization which is geared towards learning.

H3. Learning orientation has a positive influence on relationship orientation. Furthermore, the museum's desire to boost its links with visitors and donors will provide the springboard for the implementation of new technological progress linked to the relations with visitor or donor, such as databases and software applications adapted to managing friends and members, use of computers for educational programmes, information for visitors through computers or screens, webpages with video tours and virtual visits, and so on. Therefore, we posit that:

H4. Relationship orientation has a positive influence on technological innovations.

\section{Direct and indirect effect of organizational learning on performance}

Assessing performance in non-profit organizations is complex due to the absence of any single criterion on which performance may be judged (Barman, 2007). Moreover, the need to meet the interests of different publics (donors, volunteers, beneficiaries, etc.) further complicates assessment. Several authors (Andreasen and Kotler, 2002; Mottner and Ford, 2004; McMillan et al., 2005; Gainer and Padanyi, 2005) point out that the results to emerge from a marketing strategy applied to museums must be assessed in both economic and non-economic terms. Following on from these approaches, in our study we consider two types of performance: economic and social. 
The economic perspective is related to the acquisition of resources, boosting visitor numbers, increasing the number of members, job creation or generating funds through temporary exhibitions, licensing, retailing, events, grants, or sponsorship, among other aspects. All of these economic goals are aimed at safeguarding the museum's survival and profitability.

The social perspective of performance deals with the mission orientation of non-profit organizations (Olson et al., 2005). In the case of museums and cultural exhibitions, their main mission is undoubtedly to spread and foster a positive attitude towards culture and favour research and the conservation of the heritage in their custody (Kotler and Kotler, 1998), yet it may also involve offering benefits for individuals or the community as a whole, improving the standard of living of local residents or promoting the area's image.

Learning orientation underlies these outcomes and performance, either directly, through the implementation of internal changes - organizational and technological innovation or through external relations.

\subsection{Influence of organizational learning on performance}

With regard to the impact of organizational learning on performance, empirical works linking organizational learning to performance in for-profits have traditionally established that the greater the level of organizational learning the better the performance, particularly in unstable settings involving strong competition (Lei et al. 1999; Pérez et al. 2005; Bontis et al. 2002).

In the case of non-profits, the literature has demonstrated that the learning process leads to services being delivered more efficiently (Grieves and Mathews, 1997), to improved service quality (Zeilstra, 2003), or enhanced performance (Barrett et al., 2005). Wetherington (2010) reports significant positive relationships between all dimensions of 
learning organization and three measures of financial, knowledge, and mission performance. Finally, Mahmoud and Yusif (2012) examine the impact of adopting learning orientation on non-profit organizations' performance, and demonstrate that what best accounts for enhanced performance is learning orientation. To sum up, based on this empirical evidence it seems reasonable to posit the following hypotheses:

H5: Learning orientation has a positive effect on the economic performance (H5a) and social performance (H5b) of museums.

\subsection{The effect of innovation on performance}

Literature in the non-profit sector has explored the positive relationship between innovation and performance (Burt and Taylor, 2003; McDonald and Srinivasan, 2004; Voss et al., 2006; Garrido and Camarero, 2009). In the case of museums, technological and organizational innovations enable museums to create stakeholder value and, consequently, achieve high levels of performance. Organizational innovation is regarded as a strategy to enhance organizations' flexibility, competitive advantage, and performance. When museums take on staff from a range of backgrounds and when managers are trained both in business management as well as in specialized areas of culture or art, the ability to achieve both economic and social performance will be great. Moreover, organizations that are committed to acquiring and using new technologies are in a better position to respond to consumer needs and to be competitive in the markets. We thus propose that,

H6: Organizational innovation positively impacts economic performance (H6a) and social performance (H6b).

H7: Technological innovation positively impacts economic performance $(\mathrm{H} 7 \mathrm{a})$ and social performance $(\mathrm{H} 7 \mathrm{~b})$.

\subsection{The effect of relationship orientation on performance}


Several researchers (Sheth and Parvatiyar, 1995; Srivastava et al., 1998; among others) posit that relations with customers contribute to the organization's market place and economic performance. Customer relationship management processes build product awareness more quickly, encourage early product trial and promote repeat purchases and higher customer retention, each of these results supporting acceleration and enhancement of cash-flows.

Following the previous arguments, for the case of cultural organizations, we propose that the value created by relationship marketing with visitors and donors is reflected in economic and social performance. Economic performance alludes to the organization's benefits, incomes and profitability that are related to the organization's relational strategy. In this sense, cutbacks in funding from grants and contributions and increasing competition have pressured non-profits to improve accountability (Durst and Newell, 2001; Tobelem, 1997). A close and long-lasting relationship with customers (visitors and donors) usually implies a reduction in service costs and marketing costs and, in consequence, an improvement in profitability (Reinartz and Kumar, 2000; Rust et al., 2004; Camarero, 2007, among others). Social performance is also easier to achieve when museums foster closer relationships with visitors and donors. A greater commitment towards relations with visitors and donors facilitates the museum's social mission in the sense that such a commitment is in turn key to boosting visitor and donor commitment, in the shape of more visits or larger donations. Visitor and donor commitment will thus help the museum to achieve its social mission, namely improvements in the collection and in conservation, awareness and reputation and, in sum, social impact.

H8: Relationship orientation positively impacts economic performance (H8a) and social performance $(\mathrm{H} 8 \mathrm{~b})$. 


\section{Research method and results}

\subsection{Sampling}

The empirical work is based on the analysis of information provided by a sample of British, French, Italian and Spanish museums. A questionnaire was sent to museum curators. A letter was attached to the questionnaire explaining that the questionnaire should be answered by the curator or by the general manager whenever the curator was not responsible for the general management of the museum. Drawing up the questionnaire first required a thorough analysis of the particular features of this kind of organization as well as holding several meetings with some museum curators (only in Spain). This initial contact enabled us to draw up a pre-test which yielded the final questionnaire after several filters were applied.

The domain consisted of 3,500 museums (800 British, 1000 French, 800 Italian, and 900 Spanish) included in the respective Ministry of Culture websites. The total number or responses gathered throughout the process once the incomplete questionnaires had been removed was 491 (110 British, 142 French, 104 Italian, and 135 Spanish), representing a response rate of 14.0 percent, similar to other research focusing on similar goals.

The museums comprising the sample covered various thematic areas; archaeology, contemporary art, decorative art, fine arts, science and technology, natural science, ethnography and anthropology or history (Table 1). As regards museum size and management, Table 1 shows the distribution of each country sample by size and management.

Insert here Table 1

\subsection{Measurement of constructs and validation}


As for the measures of the various concepts, we adopted those existing scales previously validated by other authors, adapting the items to the area of museums. Items were measured on a scale of five points, 1 indicating "Strongly disagree" and 5 "Strongly agree".

Learning orientation was measured based on the scale proposed by Sinkula et al. (1997) and Baker and Sinkula (1999b). It should be remembered that these authors suggest a scale comprising three dimensions: commitment to learn, open mind and shared vision. Therefore, the scale was validated using a second-order confirmatory factorial analysis and reduced to a factor (latent factor provided by Lisrel 8 in the confirmatory factorial analysis).The scale was validated as a Type I second-order model following the classification proposed by Jarvis et al. (2003), in other words, considering both firstorder and second-order constructs as reflective $\left(\chi^{2}(40)=162.879 \quad(\mathrm{p}=0.000)\right.$; RMSEA=0.078; GFI=0.944; AGFI=0.907; $\mathrm{CFI}=0.972$ ).

Relationship orientation was measured by a five-item scale comprising the existence of mutual commitment and trust in the relationship with visitors and donors, the long-term orientation of these relationships and the investment of resources and time in the development of relationships with visitors and donors. This scale was specifically created for this study and this context on the basis of items proposed in scales measuring relationship orientation in different contexts (Anderson and Narus, 1990; Morgan and Hunt, 1994; Palmatier et al., 2008). As Palmatier et al. (2008) indicate, our goal was to generate a scale to assess the museum's need and investment to engage in a durable relationship with visitors and donors.

Organizational innovation is reflected on a formative scale of three indicators which refer to organizational changes, particularly the existence of a multidisciplinary management approach with a greater presence in areas of business management 
(Damanpour, 1991; Han et al., 1998; Agarwal et al., 2003). In order to validate these two scales, we carried out a first-order confirmatory factorial analysis $\left(\chi^{2}(13)=22.53\right.$ $(\mathrm{p}=0.048) ; \mathrm{RMSEA}=0.039 ; \mathrm{GFI}=0.987 ; \mathrm{AGFI}=0.972 ; \mathrm{CFI}=0.992)$.

Table 2 reports the descriptive statistics (means and standard deviations), the reliability estimates, and the CFA loadings.

Insert here Table 2

Technological innovation was measured as the number of new technologies established in the museum. After a review of the main technological innovations currently applied in museums, a series of possible innovations was put to respondents who were asked to indicate whether each had been applied in the museum or not (see Table 3). Using the data gathered, we created an index of the sum of innovations, subsequently codified on a scale of 1 to 5 , as with the other variables.

Insert here Table 3

To conclude, formative scales were used to measure the results. Economic performance was gauged using a scale measuring the evolution of the museum's performance in recent years (Day and Wensley, 1988; Agarwall et al. 2003). To measure social performance, we created a scale covering the achievements accomplished vis-à-vis impact on residents and on the area or conservation as well as improvements in the collection (Mottner and Ford, 2004). As regards the validation of formative constructs, the scale needs to be internally consistent, meaning that traditional reliability and validity assessments for reflective scales may not be applied (Bagozzi, 1994). As pointed out by Diamantopoulos and Winklhofer (2001), a formative measure is essentially a multiple regression with the construct representing the dependent variable and the indicators as the predictors. Therefore, the correlation among the indicators 
leads to multi-collinearity, which can cause instability in coefficients. Diamantopoulos and Winklhofer (2001) thus suggest using normal regression diagnostics to assess formative index validity. Table 4 shows the tolerance values and variance inflation factor (VIF) for the indicators. These values evidence that multi-collinearity is not a problem in the construction of the formative indexes.

Insert here Table 4

Table 5 shows the correlation matrix and the reliability indicators for each construct. As can be seen, all squared correlations between the variables were below the average variance extracted from the respective constructs, thus supporting the measures' discriminant validity (Fornell and Larcker 1981).

Insert here Table 5

\subsection{Control variables}

Since our sample was made up of museums of quite differing sizes, we attempted to evaluate this aspect, using size as a control variable, when measuring variables and estimating the proposed model. To do this, the sample was divided into two groups depending on the median, large museums, receiving over 15,000 visitors a year $(51.4 \%$ of the sample), and small museums, receiving fewer than 15,000 visitors (48.6\% of the sample). Likewise, as a control variable we also assessed the effect of the kind of funding predominant in the museum, whether private or public.

\subsection{Measurement model invariance test}

Given that we collected data from four different countries, ensuring the invariance of the measurement models of each group proves recommendable (Steenkamp \& Baumgartner, 1998). We therefore analyzed measurement variances across the four countries using multi-group confirmatory factor analysis (only for reflective indicators 
and considering first-order variables: commitment to learn, shared vision, open mind, relationship orientation, and organizational innovation). As regards configural variance, the four groups share the same indicator structure. For its part, metric invariance refers to the equality of the factorial loads amongst groups. In this case, we constrained factor loadings to be equal across all countries, resulting in a non-significant change in the chisquared model compared to the non-constrained model: $\chi^{2}(525)=1237.236$ for the nonconstrained model and $\chi^{2}(567)=1332.147$ for the constrained model). An individual analysis of the parameters revealed that differences are only significant in a small percentage of cases as a result of which we accept partial metric invariance.

\subsection{Results}

To estimate the proposed hypotheses we created composite variables by averaging the respective scale items for each construct and conducted a path analysis. The results of the final model are shown in Table 6, Table 7 showing the total effects $\left(\chi^{2}(3)=7.236\right.$ $(\mathrm{p}=0.065) ; \mathrm{RMSEA}=0.054 ; \mathrm{GFI}=0.996 ; \mathrm{AGFI}=0.956 ; \mathrm{CFI}=0.993)$.

\begin{tabular}{c}
\hline Insert here Table 6 \\
\hline Insert here Table 7
\end{tabular}

As can be seen from these tables, hypotheses $\mathrm{H} 1$ and $\mathrm{H} 3$ are borne out with a positive and significant effect of learning orientation on organizational innovation and relational orientation, respectively, the impact on the latter variable proving considerably greater, however. In turn, both organizational innovation as well as relation orientation contribute to museums implementing large scale technological developments ( $\mathrm{H} 2$ and $\mathrm{H} 4)$.

With regard to the influence of relation orientation on performance, the direct impact is evidenced and we see how relation orientation has a positive impact on social 
performance (H5b) and, to a lesser extent, on economic performance (H5a). With regard to the indirect impact, organizational innovation has a positive influence on economic and social performance (H6a and H6b), although the same cannot be said of technological innovation, which only appears to impact economic performance (H7a), leading us to reject H7b. Finally, relation orientation seems to have the opposite effect, having a significant impact on social performance (H8b), but not on economic performance (leading us to reject $\mathrm{H} 8 \mathrm{a}$ ). Nevertheless, in table 7 we see that the indirect effect of relational orientation on economic performance, whilst minimal, is significant. The indirect effect of learning orientation also proves significant on economic performance although not on social performance.

As regards the control variables, the positive impact of size on the level of technological and organizational innovation should be highlighted. As is to be expected, larger museums evidence a greater capacity to change and innovate. The kind of management also has an effect on technological innovation with private museums showing a greater willingness to adopt this type of change.

\section{Discussion}

Organizational learning is already widely accepted by the academic community as a key strategic tool to achieve competitive advantage. However, its widespread acceptance in the for-profit sector is not matched in the non-profit sector, despite its also being a vital factor influencing changes in the strategy of non-profit organizations, such as museums. Through learning, these organizations pinpoint the information they need to understand their internal and external environments. This has led us in the present work to attempt to gauge the impact of organizational learning on changes at the internal management level (innovation) as well as changes in the external relations (relationship orientation) 
which museums engage in, and to understand to what degree these changes may lead to enhanced performance in economic and social terms.

The analysis carried out for a wide-ranging sample of European museums has evidenced that learning orientation -perceived as a commitment by the organization to learn and engender a vision shared by all those involved with the museum, and an open mind enabling museums to face up to changes and accept criticism regarding how it has traditionally been run-, has a direct impact on the museum's economic and social performance and may prove vital to the long term survival thereof. This direct impact on performance is further enhanced by the indirect impact which learning orientation exerts through internal innovation at the organizational and technological level and through management of external relations from a relational perspective. Museums geared towards learning implement the greatest number of organizational changes, taking on management staff with a background in business, thus providing a foil to the more cultural approach of the curator. This organizational innovation leads to better economic and social performance together with technological innovations which also enhance the museum's economic performance.

Furthermore, learning orientation is considered as an incentive to the development of long-term relationships. Organizational learning thus fosters and drives performance through external relations. This is an important outcome that has not previously been empirically determined in non-profit organizations. In those museums which make a deeper commitment to learning, relations with visitors and donors become closer, thus mainly boosting the museum's social achievements, in other words its ability to involve the community in its activities. Yet despite this, technological innovation does not enhance social performance, and relation orientation with visitors and donors does not boost economic performance. Whilst attracting a greater number of visitors and securing 
more income is achieved through organizational and technological innovation, the museum's integration in society and accomplishing its cultural mission is achieved and enhanced through the effort it makes in maintaining close links with its target public.

It should be pointed out that despite the influence of learning orientation on organizational change, such a change is particularly to be found in larger museums, in the same way as technological innovation is more common in larger and privately run museums.

\subsection{Managerial implications}

Several managerial implications also emerge from our research findings. As with purely profit driven organizations, paying close attention to their day-to-day running to ensure a constant appraisal thereof and engaging in a sustained effort to learn and strive towards more efficient managerial practices might be the way for museums to gain a competitive advantage. Museums (or cultural organizations) must learn from themselves, from what they do wrong and what they do right, as well as from their environment. Only in this way will they be ready to implement changes in their organizational system which will lead to technological innovations aimed at enhancing visitor experience and internal management. Learning may also help to implement more efficient mechanisms for relations with visitors and donors, thanks, for example to practices such as member loyalty policies, a commitment to donors and the setting up of a base of members who identify with and are committed to engaging in the museum's activities and pursuing its goals. These two ways will enable the organization involved in learning to achieve its objectives to an even greater degree, both with regard to attracting visitors and securing a commitment to the cultural ends the museum pursues and its commitment to society. The findings of this research should assist managers of cultural organizations to promote a relationship orientation with visitors in their search 
for breakthrough innovations. Museums must take account of visitor behaviour, experiences and preferences as input to expand technological innovations within their organizations.

The key managerial implications of our study include the fact that managers should emphasize the development of organizational learning and relational capabilities (through membership programs, online social networks, crowdfunding and crowdsourcing practices, or customer relationship management strategies, for instance). Orienting a museum's culture towards learning is likely to enhance visitor relationships and improve performance. Nevertheless, relationship marketing orientation involves the efficient management of members, that is, a deep knowledge of the kind of material and non-material best adapted to each member (Camarero and Garrido, 2011). Whilst some members need information, discounts, or special activities to maintain their relationship, others demand recognition, with others being members merely through inertia.

These implications can be extended to other non-profit organizations. Non-profit organizations seeking innovation and closer customer relationships should pay special attention to establishing an environment which fosters learning and knowledge creation through a commitment to learn, a shared vision of goals, and an open mind. Since learning orientation impacts innovation, relationships with stakeholders, and economic and social performance, cultural as well as other charitable organizations should devote time and funds to training their manager, employee, and volunteer capabilities, so as to promote individual initiatives and forge a culture of shared values and goals.

\subsection{Limitations and further research}

One initial limitation of this work is the inclusion of different kinds of museums, failing to take account of the peculiarities of each. A major undertaking for future research is to assess the relations proposed but for various kinds of museums. Depending on what 
they specialise in (fine arts, natural science, science and technology), museums may display differing attitudes with regard to the introduction of new management philosophies and a review of less efficient practices. Whereas certain museums, due to their nature (science and technology, for instance) may be more willing to change, innovate and forge links with the public, others may be more reluctant to give up conventional managerial and conservation practices. Moreover, other sources and areas of innovation such as new activities, creativity in exhibitions, or innovation in the use of communication tools (i.e., social media) should be analyzed.

A further limitation is the fact that data are taken from only one source: the museum curator. Since we examine aspects such as relationships with donors and members, drawing on different sources of information would prove interesting in order to gain a clearer insight into the quality of external relationships. Likewise, exploring the relations between museums and their public (donors and members) from the latter's standpoint would also open up a fresh line of research.

By way of a third limitation, we point to the fact that, despite substantiating the metric invariance amongst the four countries studied, we did not take account of possible differences at a structural level. A future line of research should involve a cross-cultural analysis, allowing us to ascertain whether any differences exist amongst countries with regard to the impact of learning orientation on innovation strategies and performance, differences linked mainly to national policy concerning public museum management, current legislation or the actual idiosyncratic nature of the museums in question.

Finally, measuring performance might be improved by using more objective measuring tools. It would be desirable to use real figures about the evolution in the number of visitors and donors, the number of open days, the investment in new exhibitions, etc. In the current research, we evaluate outcomes in terms of effectiveness, that is, the extent 
to which museum orientation and strategy produces the desired results in economic and social areas. However, taking into account the costs associated with these strategies might provide insights in terms of efficiency, that is, the cost-benefit balance.

\section{Acknowledgements}

This work is framed within the Research Project SEJ2007-67095/ECON funded by the Department for Research and Management of the National R\&D\&I Plan (Ministry of Science and Innovation).

\section{References}

Agarwall S, Erramilli K., Dev, CH. 2003. Market orientation and performance in service firms: role of innovation. Journal of Services Marketing 17(1):68-82.

Anderson J.C, Narus J.A. 1990. A model of distributor firm and marketing firm working partnerships, Journal of Marketing 54 (Janvier):42-58.

Andreasen AR, Kotler P. 2002. Strategic Marketing for Non-profit Organizations. $6^{\text {th }}$ ed. Englewood Cliffs, NJ. Prentice Hall.

Argyris C., Schön D. 1978. Organisational Learning: A Theory of Action Perspective, Addison-Wesley, Reading, MA.

Bagozzi R.P. 1994. Structural Equation Models in Marketing Research: Basic Principles, in Principles of Marketing Research, cap. 9:386-419, ed. Basil Blackwell Itd.

Baker WE, Sinkula JM. 1999a. The synergistic effect of market orientation and learning orientation on organizational performance, Journal of Academy of Marketing Science 27 (4): 411-27.

Baker WE, Sinkula JM. 1999b. Learning orientation, market orientation, and innovation: integrating and extending models of organisational performance, Journal of Market Focused Management, 4:295-308.

Barczak G; Kanh K, Moss, R. 2006. An exploratory investigation of NPD practices in nonprofit organizations, The Journal of Product Innovation Management, 23:512-527.

Barman E. 2007. What is the bottom line for nonprofit organizations? A history of measurement in the British voluntary sector Voluntas 18: 101-115.

Barrett H, Balloun J. Weinstein A. 2005. The impact of creativity on performance in non-profits, International Journal of Nonprofit and Voluntary Sector Marketing, 10 (4):213-223.

Beer M, Eisenstat R. 2000. The silent killers of strategy implementation and learning, Sloan Management Review 41 (4):29-40. 
Berta W, Teare G, Gilbarte E, Soberman L, Lemieux-Charles L, Davis D, Rappolt S. 2005. The contingencies of organizational learning in long-term care: Factors that affect innovation adoption, Health Care Management Review 30 (4):282-292.

Bontis N, Crossan M, Hulland J. 2002. Managing an organizational learning system by aligning stocks and flows, Journal of Management Studies 39 (4):437-469.

Burt E, Taylor J. 2003. News technologies, embedded values, and strategic change: Evidence from the U.K. voluntary sector, Nonprofit and Voluntary Sector Quarterly 32 (1):115-127.

Calantone, S. Cavusgil, T. Zhao, Y. 2002. Learning orientation, firm innovation capability, and firm performance, Industrial Marketing Management 32 (1):15-127.

Calisir, F., Cigdem, A. Guzelsoy, E. 2013. Impacts of learning orientation on product innovation performance, The Learning Organization 20 (3):176-194.

Camarero, C. 2007. Relationship orientation or service quality? What is the trigger of performance in financial and insurance services? The International Journal of Bank Marketing 25 (6): 406-426.

Camarero, C, Garrido, M.J. 2008. The role of innovation in the relation between market orientation and performance in cultural organizations, European Journal of Innovation Management 11 (3):413- 434.

Camarero, C, Garrido, M.J. 2011. Incentives, organisational identification, and relationship quality among members of fine arts museums, Journal of Service Management 22(2):266-287.

Chang, H. 2007. Critical factors and benefits in the implementation of customer relationship management, Total Quality Management 18 (5): 483-508.

Cullon, Ch, Cullon, R. 2011. Knowledge management for nonprofits: A strategy for organizational sustainability, Communications of the IIMA 11(2):13-23

Damanpour F. 1991. Organizational innovation: A meta-analysis of effects of determinants and moderators, Academy of Management Journal 34:555-590.

Day G, Wensley R. 1988. Assessing advantage: a framework for diagnosing competitive superiority, Journal of Marketint 52 (April):1-20.

Day, G.S 1994. The capabilities of market driven organizations, Journal of Marketing 58 (4): $37-52$

Diamantopoulos A, Winklhofer H. 2001. Index construction with formative indicators: An alternative to scale development, Journal of Marketing Research 38(May):269277.

Durst, S.L., Newell, C. 2001. The who, why, and how of reinvention in nonprofit organizations, Nonprofit Management and Leadership 11(4):443-57.

Easterby-Smith M, Araujo L. 1999. Organizational learning: Current debates and opportunities, in Easterby-Smith, M., J. Burgoine and L. Araujo (eds.): Organizational Learning and the Learning Organization:1-21. Sage, London.

European Commission 2006. The economy of culture in Europe. KEA European Affairs, Media Group (Turku School of Economics) and MKW Wirtschaftsforschung $\mathrm{GmbH}$. October.

Fiol MC, Lyles MA. 1985. Organisational learning, Academy of Management Review 10(4):803-13.

Florida R. 2005. The Flight of the Creative Class. Harper Business. NY.

Fornell, C., Larcker, D. 1981. Structural equation models with unobservable variables and measurement error. Journal of Marketing Research 18 (1):39-50.

Gainer B, Padanyi P. 2005. The relationship between market-oriented activities and market-oriented culture: implications for the development of market orientation in nonprofit service organizations, Journal of Business Research 58:854-862. 
Garrido, M.J., Camarero, C. 2009. Assessing the impact of organizational learning and innovation on performance in cultural organizations, International Journal of Nonprofit and Voluntary Sector Marketing 15(August):215-232.

Grieves J, Mathews B. 1997. Healthcare and the learning service, The Learning Organization 4(3):88-97.

Han J, Kim N, Srivastava R. 1998. Market orientation and organizational performance: is innovation a missing link? Journal of Marketing 62:30-45

Hull, C, Lio B. 2006. Innovation in non-profit and for-profit organizations: Visionary, strategic, and financial considerations, Journal of Change Management 6(1):53-66.

Hult, T., Ferrell, O. 1997, Global organizational learning capacity in purchasing: construct and measurement, Journal of Business Research 40(2):97-112.

Hult,T, Hurley, R., Giunipero, L. Nichols, E. 2000. Organizational learning in global supply management: a model and test of internal users and corporate buyers. Decision Sciences 31(2):293-325

Hult, T., Ketchen, D., Reus, T. 2001. Organizational Learning Capacity and Internal Customer Orientation within Strategic Sourcing Units, Journal of Quality Management 6(2):173-192.

Hult T, Snow, C. Kandemir, D. 2003. The role of entrepreneurship in building cultural competitiveness in different organizational types, Journal of Management 29(3):401

Hurley R.F, Hult G.T. 1998. Innovation, market orientation, and organizational learning: An integration and empirical examination, Journal of Marketing 62:42-54.

Ismail M. 2005. Creative climate and learning organization factors: Their contribution towards innovation, Leadership \& Organization Development Journal 26(7/8):639654.

Jarvis, C.B., MacKenzie, S.B., Podsakoff, P.M. 2003. A critical review of construct indicators and measurement model misspecification in marketing and consumer research, Journal of Consumer Research 30(2):199-218

Johnson, J. Sohi, R. 2003. The development of interfirm partnering competence: Platforms for learning, learning activities, and consequences of learning, Journal of Business Research 56:757-766.

Kotler, N. Kotler, P. 1998, Museum Strategy and Marketing, Jossey-Bass, San Francisco, CA.

Lei D, Slocum J, Pitts R. (1999). Designing organizations for competitive advantage: the power of unlearning and learning, Organizational Dynamics 37(3):24-38.

Mahmoud, M., Yusif, B. 2012. Market orientation, learning orientation, and the performance of nonprofit organisations (NPO), International Journal of Productivity and Performance Management 61(6): 624-652.

McDonald R, Srinivasan N. 2004. Technological innovations in hospitals: what kind of competitive advantage does adoption lead to? International Journal of Technology Management 28(1):103

McDonald R. 2007. An investigation of innovation in nonprofit organizations: The role of organizational mission, Nonprofit and Voluntary Sector Quarterly 36(2):256-281.

McMillan K, Money K, Money A, Downing S. 2005. Relationship marketing in the notfor-profit sector: an extension and application of the commitment-trust theory, Journal of Business Research 58: 806-818.

Morgan, R., Hunt S. 1994. The commitment-trust theory of relationship marketing, Journal of Marketing 58(3):20-38.

Mottner S, Ford J. 2004. Measuring nonprofit marketing strategy performance: the case museum store, Journal of Business Research 58(6):829-850. 
Murray, P., Carter, L. 2005. Improving marketing intelligence through learning systems and knowledge communities in not-for-profit workplaces, Journal of Workplace Learning 17(7/8):421-435.

Nason R.W. 1994. Globalization and Macromarketing, Journal of Macromarketing 14 (2): 1.

Nonaka I, Takeuchi H. 1995. The Knowledge-Creating Company, Oxford University Press, Oxford.

Olson, J., Belohlav, J., Boyer, K. 2005. Operational, economic and mission elements in not-for-profit organizations: the case of the Chicago Symphony Orchestra, Journal of Operations Management 23(2):125-42.

Palmatier, R. Scheer, L. Evans, K, Arnold, T. 2008. Achieving relationship marketing effectiveness in business-to-business exchanges, Academy of Marketing Science Journal 36(2):174-190.

Pérez S, Montes J., Vázquez C. 2005. Organizational learning as a determining factor in business performance, The Learning Organization 12(3):227-245.

Reinartz, W.J., Kumar, V. 2000. On the profitability of long-life customers in a noncontractual setting: an empirical investigation and implications for marketing, Journal of Marketing 64(4): 17-35.

Rust, R.T., Lemon, K.N., Zeithaml, V.A. 2004. Return on marketing: using customer equity to focus marketing strategy, Journal of Marketing 68(1):109-27.

Salim, I., Sulaiman, M. 2011. Organizational learning, innovation and performance: A study of Malaysian small and medium sized enterprises, International Journal of Business and Management 6(12):118-125

Santos-Vijande, L., Sanzo-Pérez, M.J., Alvarez-Gonzalez, L., Vazquez-Casielles, R. 2005. Organiational learning and market orientation: interface and effects on performance, Industrial Marketing Management 34:187-202.

Saxe, R., Weitz, B. 1982. The SOCO scale: a measure of the customer orientation of salespeople. Journal of Marketing Research 19:343-351.

Senge, P. 1990. The fifth discipline: The art and practice of the learning organization. New York: Doubleday.

Sheth, N. J., Parvatiyar, A. 1995. Relationships marketing in consumer markets: Antecedents and consequences. Journal of Academy of Marketing Science 23(4):255271.

Sinkula J, Baker W, Noordewier T. 1997. A framework for market-based organizational learning: Linking values, knowledge and behavior, Journal of the Academy of Marketing Science 25(4):305-318.

Sinkula J. 1994. Market information processing and organizational learning, Journal of Marketing 58(1):35-45.

Slater S.F, Narver J.C. 1995. Market orientation and the learning organisation, Journal of Marketing 59(July):63-74.

Srivastava, R.K., Shervani, T.A., Fahey, L. 1998. Market-based assets and shareholder value: a framework for analysis, Journal of Marketing 62 (January):2-18.

Steenkamp, J-B.E.M., Baumgartner, H. 1998. Assessing measurement invariance in cross-national consumer research. Journal of Consumer Research 25:78-90.

Tobelem, J.M. 1997. The marketing approach in museums, Museum Management and Curatorship 16(4):337-54.

Voss G, Montoya-Weiss M., Voss Z. 2006. Aligning innovation with market characteristics in the nonprofit professional theater industry, Journal of Marketing Research 43(May):296-302. 
Webster, F. 1992. The changing role of marketing in the corporation, Journal of Marketing 56(4):1-17.

Weerd-Nederhof P, Pacitti B, Da Silva Gomes J, Pearson A. 2002. Tools for the improvement of organizational learning processes in innovation, Journal of Workplace Learning 14(8):320-331.

Wetherington, J. 2010. The relationship between learning organization dimensions and performance in the non-profit sector. Dissertations, University of Phoenix.

Williams, J. 1992. How sustainable is your competitive advantage? California Management Review 34:29-51.

Yim-Teo T. 2002. Learning organization a cultural breakthrough in the public sector, The Journal of Applied Management and Entrepreneurship 7(3):48-71.

Zeilstra D. 2003. Reciprocal learning in teams: Relational practices for securing the best from leadership volunteers in nonprofit organizations, PhD dissertation, Case Western Reserve University, Weatherhead School of Management. 
Table 1 Sample description

\begin{tabular}{|c|c|c|c|c|}
\hline & France & Italy & Spain & $\begin{array}{c}\text { United } \\
\text { Kingdom }\end{array}$ \\
\hline \multicolumn{5}{|l|}{ Type of museum* } \\
\hline Archaeological & $32.4 \%$ & $34.6 \%$ & $23.0 \%$ & $19.1 \%$ \\
\hline Contemporary Art & $8.5 \%$ & $5.8 \%$ & $14.1 \%$ & $6.4 \%$ \\
\hline Decorative Art & $22.5 \%$ & $3.8 \%$ & $6.7 \%$ & $16.4 \%$ \\
\hline Fine arts & $37.3 \%$ & $26.9 \%$ & $17.8 \%$ & $20.0 \%$ \\
\hline House-Centre & $1.4 \%$ & $3.8 \%$ & $2.2 \%$ & $9.1 \%$ \\
\hline Science and technology & $8.5 \%$ & $9.6 \%$ & $7.4 \%$ & $10.0 \%$ \\
\hline Natural sciences & $12.7 \%$ & $12.5 \%$ & $6.7 \%$ & $10.9 \%$ \\
\hline Place & $8.5 \%$ & $10.6 \%$ & $3.0 \%$ & $18.2 \%$ \\
\hline Specialized & $5.6 \%$ & $10.6 \%$ & $14.8 \%$ & $10.9 \%$ \\
\hline Ethnography \& anthropology & $24.6 \%$ & $6.7 \%$ & $22.2 \%$ & $6.4 \%$ \\
\hline History & $36.6 \%$ & $8.7 \%$ & $15.6 \%$ & $39.1 \%$ \\
\hline Other & $11.3 \%$ & $0.0 \%$ & $8.9 \%$ & $0.0 \%$ \\
\hline \multicolumn{5}{|l|}{ Size } \\
\hline Less than 5,000 & $18.3 \%$ & $38.5 \%$ & $20.7 \%$ & $20.9 \%$ \\
\hline Between 5,000 and 10,000 & $20.4 \%$ & $15.4 \%$ & $13.3 \%$ & $10.9 \%$ \\
\hline Between 10,000 and 25,000 & $21.1 \%$ & $15.4 \%$ & $21.5 \%$ & $18.2 \%$ \\
\hline Between 25,000 and 50,000 & $16.9 \%$ & $9.6 \%$ & $13.3 \%$ & $18.2 \%$ \\
\hline Between 50,000 and 100,000 & $9.9 \%$ & $4.8 \%$ & $9.6 \%$ & $10.0 \%$ \\
\hline Over 100,000 & $2.8 \%$ & $10.6 \%$ & $12.6 \%$ & $20.9 \%$ \\
\hline \multicolumn{5}{|l|}{ Management } \\
\hline Public & $86.6 \%$ & $67.3 \%$ & $74.8 \%$ & $52.7 \%$ \\
\hline Private & $12.0 \%$ & $32.7 \%$ & $23.0 \%$ & $46.4 \%$ \\
\hline
\end{tabular}

(*) These categories are not exclusive. Several museums are included in more than one category. 
Table 2 Measurement variables: descriptive statistics, reliability and CFA loadings.

\begin{tabular}{|c|c|c|}
\hline Indicators & Mean (S.D.) & Loadings \\
\hline \multicolumn{3}{|l|}{ Learning orientation $(C R=0.909 A V E=0.771)$} \\
\hline Commitment to learn & & 0.786 \\
\hline $\begin{array}{l}\text { Management supposes that the ability to learn is one of the major keys to achieving } \\
\text { competitive advantage. }\end{array}$ & $4.20(0.93)$ & 0.700 \\
\hline $\begin{array}{l}\text { In this museum there is a shared conviction at all levels that learning is necessary in order to } \\
\text { improve and ensure efficiency. }\end{array}$ & $4.03(0.96)$ & 0.741 \\
\hline We feel that learning/training for staff is an investment not an expense. & $4.08(1.12)$ & 0.588 \\
\hline $\begin{array}{l}\text { We believe that forgoing organizational learning jeopardises the long-term survival of the } \\
\text { museum. }\end{array}$ & $3.95(1.02)$ & 0.544 \\
\hline Shared vision & & 0.882 \\
\hline $\begin{array}{l}\text { In the museum the idea of "who we are" is clearly defined, in other words, what our mission is } \\
\text { and what our long term goals are. }\end{array}$ & $4.19(0.97)$ & 0.652 \\
\hline The museum staff are fully committed to achieving these goals. & $3.84(1.03)$ & 0.725 \\
\hline The staff feel themselves to be involved in the design of the future running of the museum. & $3.70(1.06)$ & 0.724 \\
\hline Senior management staff share with junior staff their vision of the museum's future. & $3.79(1.08)$ & (a) \\
\hline $\begin{array}{l}\text { The vision of what the museum is and its purpose is shared at all levels of the organization. } \\
\text { Open mind }\end{array}$ & 3.79 (1.07) & 0.747 \\
\hline $\begin{array}{l}\text { We are not afraid to question or reflect critically on the way the museum has traditionally been } \\
\text { run or on long-standing beliefs. }\end{array}$ & $3.78(1.11)$ & 0.635 \\
\hline $\begin{array}{l}\text { We believe that it is extremely important to work with an open mind, and to be ready to adopt } \\
\text { alternative solutions to the traditional way of doing things. }\end{array}$ & $4.32(0.89)$ & 0.702 \\
\hline Staff are encouraged to come up with original ideas. & $4.12(1.04)$ & 0.802 \\
\hline \multicolumn{3}{|l|}{ Organizational Innovation $(C R=0.743 \mathrm{AVE}=0.505)$} \\
\hline $\begin{array}{l}\text { In general, in recent years significant changes have been introduced into the museum's } \\
\text { organizational structure. }\end{array}$ & $3.31(1.42)$ & 0.622 \\
\hline The museum management has a background and training in business management. & $2.86(1.37)$ & 0.779 \\
\hline The museum management strives to take on staff from a range of training backgrounds. & $3.11(1.39)$ & 0.971 \\
\hline \multicolumn{3}{|l|}{ Relational orientation $(C R=0.829 A V E=0.556)$} \\
\hline $\begin{array}{l}\text { Relations with our main donors and friends are founded on commitment and mutual trust and } \\
\text { are conducted on a stable basis. }\end{array}$ & $3.98(1.02)$ & 0.835 \\
\hline We strive to establish long-lasting relations with our main donors and friends. & $4.04(1.03)$ & 0.873 \\
\hline We invest resources to strengthen our links to the museum's donors and friends. & $3.63(2.69)$ & (a) \\
\hline $\begin{array}{l}\text { When faced with compromising circumstances, we feel that our main donors and friends will } \\
\text { respond positively, thanks to the relations forged with them. }\end{array}$ & $3.63(1.11)$ & 0.660 \\
\hline $\begin{array}{l}\text { We feel that it is worth investing time and effort in training staff specialised in dealing not only } \\
\text { with visitors but also with our donors and friends. }\end{array}$ & $3.80(1.07)$ & 0.572 \\
\hline
\end{tabular}


Table 3 Indicators of technological innovation

Technological Innovations

Percentage

Digitized catalogue of the book collections

$26.7 \%$

Digitized catalogue of the items in the gift shop or bookshop

$12.8 \%$

Digitization of the archives, books or historical documents

$29.9 \%$

Digitization of images or photograph

$59.1 \%$

Digitization of works in the collection

$48.5 \%$

Software applications adapted to managing the collection

$42.0 \%$

Databases of friends of the museum and member

Software applications adapted to managing friends and members

$41.5 \%$

Staff training programmes

$11.8 \%$

Use of computers for educational programmes

$26.7 \%$

Information for visitors through computers or screens

$30.5 \%$

$33.4 \%$

Projection screens with video tours around the museum

$19.6 \%$

Screens with virtual visits around the museum accessible to visitors $\quad 13.6 \%$

Presentation of content through photographic panels or with images $\quad 46.2 \%$

$36.2 \%$

Environmental scenography

$30.1 \%$

Informative screens on techniques, materials, exhibited works, etc. $\quad 23.4 \%$

Webpage

$23.4 \%$

Webpage with video tours

$6.3 \%$

Webpage with virtual visit

$14.3 \%$

Educational programmes on the web

$15.9 \%$

Dissemination of research or publications through the web 
Table 4 Measurement variables: descriptive statistics and multicollinearity values.

\begin{tabular}{lccc}
\hline Indicators & Mean (S.D.) & Toler. & VIF \\
\hline Economic performance & & \\
\hline Over the last three years the centre's own revenue has increased & $3.12(1.35)$ & 0.64 & 1.55 \\
Over the last three years jobs have been created & $2.73(1.55)$ & 0.82 & 1.21 \\
Over the last three years the number of visitors has risen & $3.49(1.34)$ & 0.73 & 1.36 \\
Over the last three years our centre has fully accomplished its financial goals & $3.07(1.24)$ & 0.80 & 1.23 \\
\hline Social performance & & & 1.31 \\
\hline Our centre is helping to improve the life of local residents & $3.49(1.13)$ & 0.76 & 1.20 \\
Over the past three years our centre has fulfilled its goals with regard to the & $3.82(1.00)$ & 0.83 & \\
conservation or improvement of the collections it houses & & \\
The centre has contributed to a greater awareness on the part of the community of & $4.03(0.85)$ & 0.72 & 1.38 \\
the works displayed & $3.88(1.07)$ & 0.71 & 1.40 \\
Our centre has become a cultural reference point for the area & &
\end{tabular}


Table 5 Correlation matrix

\begin{tabular}{|c|c|c|c|c|c|c|}
\hline & $\begin{array}{l}\text { Learning } \\
\text { orientation }\end{array}$ & $\begin{array}{c}\text { Organizational } \\
\text { innovation }\end{array}$ & $\begin{array}{c}\text { Relationship } \\
\text { orientation }\end{array}$ & $\begin{array}{c}\text { Technological } \\
\text { innovation }\end{array}$ & $\begin{array}{c}\text { Economic } \\
\text { performance }\end{array}$ & $\begin{array}{c}\text { Social } \\
\text { performance }\end{array}$ \\
\hline \multicolumn{7}{|l|}{ Learning orientation } \\
\hline Organizational innovation & 0.238 & & & & & \\
\hline Relationship orientation & 0.441 & 0.103 & & & & \\
\hline Technological innovation & 0.105 & 0.341 & 0.117 & n.a. & & \\
\hline Economic performance & 0.217 & 0.409 & 0.174 & 0.361 & n.a. & \\
\hline Social performance & 0.327 & 0.267 & 0.295 & 0.179 & 0.180 & n.a. \\
\hline
\end{tabular}


Table 6 Estimated relationships

\begin{tabular}{|c|c|c|c|}
\hline Hypotheses & $\begin{array}{l}\text { Standardized } \\
\text { estimators }\end{array}$ & t-value & \\
\hline H1. Learning orientation $\rightarrow$ Organizational innovation & 0.241 & $5.519 * * *$ & Accepted \\
\hline H2. Organizational innovation $\rightarrow$ Technological innovation & 0.291 & $7.055 * * *$ & Accepted \\
\hline H3. Learning orientation $\rightarrow$ Relationship orientation & 0.441 & $10.817 * * *$ & Accepted \\
\hline H4. Relationship orientation $\rightarrow$ Technological innovation & 0.093 & $2.288 * *$ & Accepted \\
\hline H5a. Learning orientation $\rightarrow$ Economic performance & 0.093 & $2.060 * *$ & Accepted \\
\hline H5b. Learning orientation $\rightarrow$ Social performance & 0.206 & $4.393 * * *$ & Accepted \\
\hline H6a. Organizational innovation $\rightarrow$ Economic performance & 0.296 & $6.886 * * *$ & Accepted \\
\hline H6b. Organizational innovation $\rightarrow$ Social performance & 0.173 & $3.878 * * *$ & Accepted \\
\hline H7a. Technological innovation $\rightarrow$ Economic performance & 0.224 & $5.101 * * *$ & Accepted \\
\hline H7b. Technological innovation $\rightarrow$ Social performance & 0.066 & 1.441 & Rejected \\
\hline H8a. Relationship orientation $\rightarrow$ Economic performance & 0.079 & 1.805 & Rejected \\
\hline H8b. Relationship orientation $\rightarrow$ Social performance & 0.183 & $3.991 * * *$ & Accepted \\
\hline \multicolumn{4}{|l|}{ Control variables $^{a}$} \\
\hline Size $\rightarrow$ Organizational innovation & 0.147 & $3.353 * * *$ & \\
\hline Funding $\rightarrow$ Organizational innovation & -0.041 & -0.940 & \\
\hline Size $\rightarrow$ Relationship orientation & -0.016 & -0.387 & \\
\hline Funding $\rightarrow$ Relationship orientation & 0.005 & 0.132 & \\
\hline Size $\rightarrow$ Technological innovation & 0.273 & $6.626 * * *$ & \\
\hline Funding $\rightarrow$ Technological innovation & -0.092 & $-2.256 * *$ & \\
\hline Size $\rightarrow$ Economic performance & 0.065 & 1.558 & \\
\hline Funding $\rightarrow$ Economic performance & 0.030 & 0.749 & \\
\hline Size $\rightarrow$ Social performance & 0.055 & 1.274 & \\
\hline Funding $\rightarrow$ Social performance & 0.065 & 1.557 & \\
\hline
\end{tabular}


Table 7 Indirect effects

\begin{tabular}{lccc}
\hline & $\begin{array}{c}\text { Learning } \\
\text { orientation }\end{array}$ & $\begin{array}{c}\text { Relationship } \\
\text { orientation }\end{array}$ & $\begin{array}{c}\text { Organizational } \\
\text { innovation }\end{array}$ \\
\hline Technological innovation & $0.111^{* * *}$ & & \\
Economic performance & $0.131^{* * *}$ & $0.021 * *$ & $0.065^{* * *}$ \\
Social performance & $0.130^{* * *}$ & 0.006 & 0.019 \\
\hline
\end{tabular}

